\title{
Postmodern Discourse and Its Semiosis
}

\author{
Kseniya Hakobyan \\ Moscow State Institute of International Relations (MGIMO University), Russia \\ Correspondes concerning this article should be addressed to Kseniya Hakobyan, Department of English \\ \#5, Moscow MGIMO University, 76 Prospect Vernadskogo, Moscow, Russian Federation, 119454. E-mail: \\ solodovnikk@mail.ru
}

\author{
Jasmina Šuler-Galos \\ University of Warsaw
}

\begin{abstract}
Correspondes concerning this article should be addressed to Dr. Jasmina Šuler-Galos, Faculty of Polish Studies, Institute of Western and Southern Slavic, University of Warsaw, Krakowskie Przedmieście 26/28, PL-00-927 Warsaw.E-mail: jasmina.galos@gmail.com
\end{abstract}

Symbolic representation is a specific, uniquely human form of objectification of the real world, a powerful means of communication activity of its reflectivity. Understanding of the phenomenon of sign representation, its modeling and the definition of the sign and its meaning depends on the sign language system and aspects of the language to be interpreted - dynamic or statistical, functional or structural aspects are taken as a basis. This article is an attempt to review the main components of the sign of the postmodern discourse.

It should be noted that in modern science there is a tendency to revise the linguistic nature of the sign. Among all areas of linguistics there is a domination of the theoretical reflection, according to which all phenomena are regarded as the implementation of language text, discourse, narrative. Therefore, the full range of human culture is the sum of texts of the intertextuality. Consciousness also appears in the form of text that can be read by the relevant rules of grammar, or, by using the decryption of codes. Foreign linguists developed a new direction in science: the main emphasis is placed on the special role of the interpretation procedures and the importance of reading both cognitive and communicative signs, because any schematization of reality is a sign. The analysis of postmodern texts suggests that thought can not be just interpreted, but also disinterpreted in postmodern discourse. In these texts, the notion of the sign takes on a different, broader meaning than that of word mark. One of the important issues of semiotic analysis of postmodern discourse is to examine and identify the codes that exist to decipher all kinds of signs.

Thus, in the context of our research the quite relevant question is to define the temporal signs (linguistic or non-linguistic) to be expressed in the postmodern discourse. As is known, the category of 'time' appears as a symbol of life / death, meaning as a cultural reality, and so forth. In modern linguistics it is assumed that postmodern text is regulated by a set of codes: the linguistic code of natural language, the literary code that defines the connectivity of the text, the genre code, and meta-language of a writer. In our view, the essence of postmodern discourse is a combination of mosaic codes, which include the following types of: linguistic, cultural, semiological, interactive, and metatextual codes.

Keywords: sign representation, sign, text, discourse, intertextuality, code, decryption, interpretation procedure, postmodernism, semiotic analysis, meta-language

Problems of perception/interpretation of texts at the end of the twentieth century touches on a range of issues associated with the representation of the text as a sign. Semiotic methodology allows us to present conditional reality as a communicative process, regulated by a system of codes and signs, which prompt the corresponding reaction from the addressee recipient. The semiotic "subject-object" interaction, carried out by means of certain sign systems and sets of meanings, represents a certain level of language of 
communication. Sign representation of conventional art is actually a specific form of objectification of the real world and is a considerable indicator of its reflective communicative activity.

The conceptual postmodern picture of the world can be represented as a communicative interaction between various and often protean sides: the subject and object (the moderator/author of conventional art and the individual/reader are immersed in this reality). The moderator of postmodern conditional reality along with the hero/reader interact in the pursuit of understanding each other based on the condition that communication in the same language uses the same symbols and signs, which are equivalent for all participants of the communicative interaction. If this condition is met, then the interaction between the two sides is considered valid communication.

M. M. Bakhtin in one of his early works, Marxism and the Philosophy of Language, wrote about a synchronicity of any language, and the existence of language only from the point of view of the subject, allocating with a certain semantic meaning these or those verbal structures (Bakhtin, 2000). Indeed, only that meaning which is embedded in verbal structure by all the participants of verbal interactions, makes a specific set of spoken sounds into a common sign that shows any objectively-existing social phenomenon or theoretical construct. Formation of the system of the standard symbols and signs makes possible any communicative interaction between subjects and objects of discursive space.

The language of postmodern discursive practices in its semiotic formulation acts as a kind of code which contains certain meanings, rather adequately and unambiguously perceived by subjects and by all objects of communicative interaction. It is necessary to note that there is no fixed interpretation of the nature of language or definition of a sign. Among the total number of existing interpretations there are structuralist and poststructuralist theories, starting from the ideas of Baudouin de Courtenay and Ferdinand de Saussure to representations of J. Lacan, J. Derrida, J. Kristeva. Thus structuralist interpretations of language sign have a bilateral psychic entity connecting concept and acoustic image. In poststructuralist practice, the language sign has absorbed the essence of epistemological uncertainty, revealing "existence created from absence" (Lacan, 1977, p. 65); that is, the language sign has actually lost its representative function. Thus, the essence of sign representation is the replacement and generalization of things.

A language sign as an empirical construct of discursive practices is multivariate, and each option of a sign model has its form of a materialization and functional characteristics. I.P. Ilyin states, in his book Postmodernism: Glossary, that postmodernism revised the linguistic nature of a language sign, taking everything as a text, a discourse, which can be read by the relevant rules of grammar, constructed by analogy with grammar of a natural language (Ilyin, 2001). The postmodern phenomena of language implementation are reviewed and analyzed at the level of pragmatics and theoretical reflection, according to which the conditional constructs and models of reality are considered at the level of discursive practices. The sense of essence and phenomenon is not generated in mimesis, but in semiosis, i.e., in the free game of interpretations and values of different interpretations of texts and discourses. Therefore, the full range of human culture is presented as the sum of the texts. According to the English literary critic and novelist Walter Allen, the continuity of tradition depends on innovation (Allen, 1964, p. 214). And, in fact, we can get innovation only in the context of tradition. The classical heritage of the past was described from new methodological positions and by the new language, which helped to identify and update hidden sides of artists' works.

\section{Materials and Methods}

\section{Correlation of 'Text' and 'Discourse'}

The modern stage in the development of philology faces one of its most difficult issues in distinguishing the terms 'text' and 'discourse'; so the theory of comparative linguistics offers the theory of a comparative discourse studies, which is just beginning to be confirmed by the emergence of a number of works (Kashkin, 2007; Uhvanova-Shmygova, 2009). To determine the nature of discursive space is quite difficult; it is possible to assume that reality is unfolding as existing elements that clash as a result of a system of interaction, interdependence and mutual influence. At the same time the concept of text is legitimately used to designate any linguistic material in its written form, and as a synonym for discourse, if this text is its own written representation.

For a linguist, the essence of a text is, first and foremost, the language material fixed in writing (Szczerba, 1974, p. 26), whose usage might establish certain regularities in the deployment of the discursive process, in the structure of the language system, and also in the identification of various properties of language units. Depending on the theoretical setting, the text may be considered as a sequence of units at any level (words, phrases, phonemes, etc.), not only as a sequence of proposals. At the same time, any text and any statement always assumes the recipient and is directed to the recipient, and involves their reaction. "Discourse is a new feature to form a Language, as it 


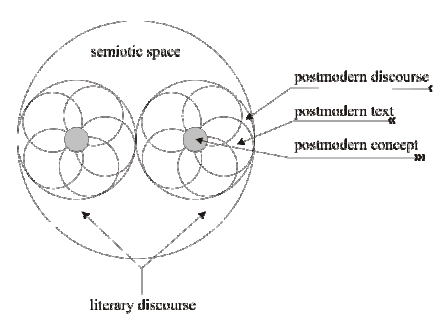

Figure 1. The multidimensionality of a discourse.

appeared before us at the end of twentieth century" (Stepanov, 1996, p. 71).

Linguists use the concept of discourse to explore the dynamic elements of language. The terms 'text' and 'discourse' can be opposed to each other in the concept of the act of creation as a result of creation (what has been told) and the process of creating (speech); we are led to this observation by the works of E. S. Kubryakova, O. V. Alexandrova, V. G. Kostomarov and N. D. Zarubina. The category of text should be considered as an elementary unit of a discourse; in order to understand such a complex communicative phenomenon as a discourse, it is necessary to consider the importance of extra-linguistic factors (knowledge of the world, opinions, attitudes, goals of a sender), that also N. D. Arutyunova, Yu. N. Karaulov, N. N. Mironova and other researchers note.

The multidimensionality of a discourse caused, in particular, the multiplicity of its definitions (Fig. 1) and a relatively rapid evolution in concepts even within the same scientific field. Among a large number of interpretations of the concept of discourse, the most interesting theoretical justifications are in Sémiotique, Dictionnaire raisonné de la théorie du langage (Semiotics, The explanatory dictionary of a language theory) by A. J. Greimas and J. Courtés. Discourse is interpreted as a semiotic process, which is realized in different types of discursive practices (Greimas, Courtes, 1983).

In speech activity a discourse is represented as a unit that belongs to a higher level of language, consisting of sentences linked within meaning. All syntactic and semantic processes, which are characteristic for the levels of words and sentences, are caused by the structure of the entire discourse as a relatively independent language unit of a higher order. Discourse, however, differs from the lower units of a language in that it cannot be reproduced like phonemes and morphemes, but it is created in speech. We consider the phenomenon of discourse as a speech-and-thought process presented in a set of intertexts related to each other by common cognitive strategies, having an internal organization consistent with these strategies to transfer the meaning.

The collection of texts, united on various grounds, is implemented in the corresponding type of discourse. National discourses (Russian, English, etc.) are delimited; within national discourse there are poetic, aesthetic, scientific, critical, educational, legal, political and other discourses. Developing the dialogical approach (developed by J. Kristeva (Kristeva, 1993)) relying on the criteria of the typology of discourse proposed by M. Foucault (the attitude towards the author, the expressive value of discourses, openness for transformation, ways of adaptation of discourses to culture (Foucault, 2005)), we believe it is possible to speak about the existence of so-called 'post-modern discourse' combining texts that are based on common principles of postmodernism.

The main features of the postmodern writing as a specific attitude and world mapping are the conscious destruction of boundaries of artistic space and incoherence, whose purpose is the aesthetic shock that can push the boundaries of the conventional understanding of the world. According to I. P. Ilyin, postmodern characteristics are combinations (in one textual space) of the obviously actual and the obviously fictitious, an introduction of the author to the text, and thus the statement of a question of the authorship, an exposure of conventions of literature in the course of their use (Ilyin, 1998, p. 86).

Among its principal instruments, there is primarily an ironic attitude toward immutable standards, which in the medium of art and graphic means generates a socalled 'naked reception'. Postmodern communication is further characterized as a volatile and fluid space in which the text is formed by a succession of comments and notes to itself; there are significant traditions from previous epochs, which are presented in the form of quotations from earlier texts, but with ttransformed value. The presence of such properties transforms the text into an infinite system, which is more similar to the concept of inter-textuality. Postmodern discourse comprises a collection of texts-intertexts, actualizing the incompleteness of postmodernist writing, which remains a continuous process of designing signs, forming a special model of the world.

The concept of inter-textuality is closely related to the phenomenon of depersonalization as the subjectivity of a text, disappearing in citations, entailing a crisis of personal principle. The so-called dissolving of 'a character in the novel' (Dranov, Ilyin, \& Kozlov, 1996, p. 207) is a consequence of the fact that the image of a man has lost integrity in postmodern literature; in the literary work, the reader hears a voice from the 
text which was organized in accordance with the rules of cultural coding of its time, but not the voice of the author. Functions of literature radically change, the era of the reader comes, and the birth of the reader has to occur due to the death of the author (Ilyin, 1998, p. 95). Postmodern literature draws extremely pessimistic conclusions about the possibility of the continued existence of a literary character and connects it with the lack of a full-blooded character: "The dissolution of a character is a conscious victim of postmodernism" (Ilyin, 1998, p. 92).

In this genre, the author's mask can frequently be that of a real narrative hero, capable of attracting the reader's attention. Organization of the postmodern text consists of a deliberate randomness and fragmentation of the composition, so the author's mask is the main means of maintaining communication and the important structure-forming principle of the narrative manner of postmodernism. The image of the author acts in the text as a binding center, which turns separate material into a whole. The author's mask provides the necessary literary communicative situation that prevents the work from 'communication failure' (Dranov, Ilyin, \& Kozlov, 1996, p. 192). This interpretation of postmodern writing is based on studying the signs of systemic categories of postmodern discourse:

- Creolized texts and multiple codes (the code is a set of rules organizing the text of a work of art),

- The author's mask and intertextuality which are inextricably linked with each other and determine one another.

Thus, the discursive understanding of reality finds its preferential embodiment in the central property of postmodern poetics - in inter-textuality (the term coined by J. Kristeva (Kristeva, 1993)). In M. M. Bakhtin's theory it corresponds to an idea of literature as a continuous dialogue between the author and the reader, as well as with all current and previous culture (Bakhtin, 1979, p. 59). Yu. M. Lotman, understanding culture in general as a text, emphasizes that it is a difficultly arranged text, breaking up into a hierarchy of 'a text in a text' and forming a complex weave of texts (Lotman, 1970, p. 81). In other words, each new work is considered as a complete and independent text, which acts as a kind of quotation from the infinite texts of culture.

For example, T. Stoppard displays in the play Rosencrantz and Guildenstern Are Dead (1967) an ironic outperformance of Shakespeare's immortal play The Tragedy of Hamlet, Prince of Denmark (16001601 ), changing an angle of vision of the problems put forward by the British classic. Stoppard sharpens the problem of the role of art in the general ordinary flow of life, as well as the problem of an assessment of the impact of art on the entirety of ordinary life, raising the problem of the existence of 'art for art's sake'. The author resorts to all sorts of simulations and philosophical wordplay, while, all action played out is just an illusion, taking place and in a vacuum.

Rosencrantz and Guildenstern try on the masks to adjust to the scenery set by the author, but, nevertheless, as suggested by the title, the author's intention regarding the fate of his characters is already clear from the outset. Stoppard plays with the puppet characters of Rosencrantz and Guildenstern, putting them first in a void, in a vacuum, in which there is neither time nor well-organized space, revealing their inner potential as heroes. It turns out that Rosencrantz and Guildenstern are hollow characters, which captures the essence of postmodern vision of the world as the world of the chaotic capable of an expanse of emptiness. The analysis, as well as the representation and appearance on the scene of hollow characters, testifies to the metaphysical essence of such characters, that is, they are able to set us a new vision of universal projections.

Owing to figures like Rosencrantz and Guildenstern, who don the hypocritical masks of servile supporters to those who are on the throne (in our case, Claudius and Gertrude) and meanwhile act as 'true' friends of Hamlet, readers are in a difficult kaleidoscopic situation. As in Shakespeare's 'theater in the theater', Stoppard's fragments of theatrical performances in an outline of the overall integrated setting enable us not only to observe the implementation of a given plot with delight, but also to reflect on the multifaceted world containing in itself both real actions and artificially (personally) simulated situations-simulacra.

Along with inter-textuality, there is a systemforming category of a game principle in postmodern discourse. The game principle was the implementation of the ironic origin of postmodern culture. Most successfully, in our opinion, game strategy of postmodernism has been defined by S. Isaev, who has argued that meta-semantics is characteristic for postmodern works and can be achieved through a variety of connotative means. However, these tools can be described with just one word - a game. With the advent of postmodernism there comes an epoch, when the relationship between art and meaning disappears: and now such a relationship is just a game. Equating the rights of real and fictitious, the game leads to a situation of an unlimited number of meanings in the work: after all, its meaning is not connected with preexisting reality (Isaev, 1992, pp. 7-8).

English postmodernist J. Fowles exposes the radical rethinking of traditional poetics, existing artistic means and even the material of Belles Lettres - the language itself. One means of radical rethinking is a language game. The definition of a language game includes a wide range of concepts. It acts as a form of perception of the world marking the advent of a new stage in the development of poetics, that is the stage of self-reflection. It is no longer possible to 


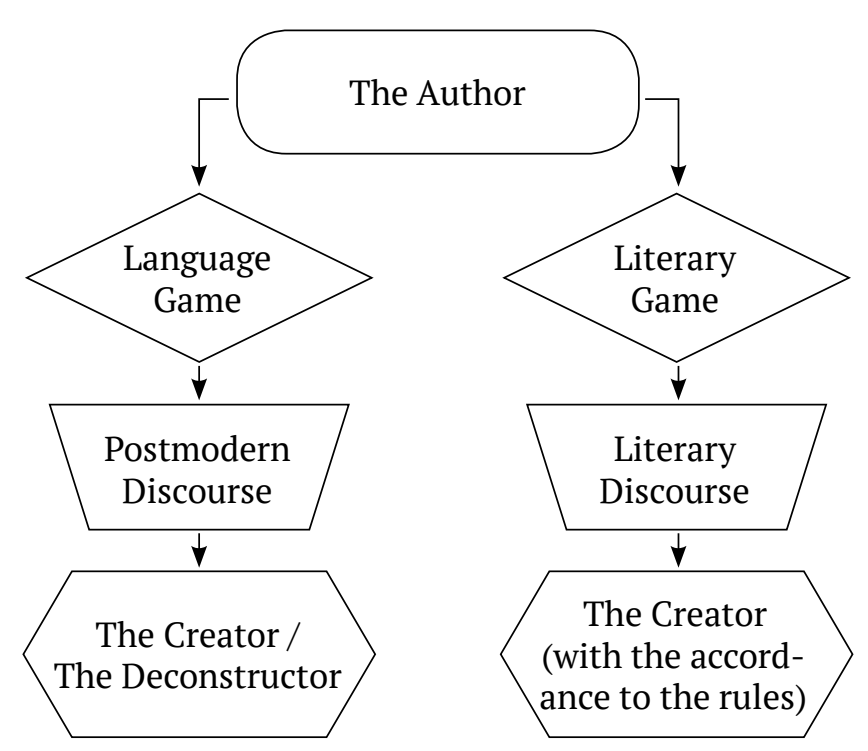

Figure 2. Strategies of creative behavior of the author.

meditatively take reality presented by language (in this case it would be possible to talk about attitudes toward the world); there is an attempt to influence it actively, or rather, to affect the perception of reality by the only available means: through an influence on the language. Of course, each postmodernist performs this task in their own way, but a demonstration of the general strategy of creative behavior is symptomatic and is typical for today's literary situation, which seems to be moving in a postmodern direction. For the language game in the works by Fowles, the free establishment and violation of the author's own rules and regulations is characteristic (actually a literary language game, where the strict implementation of regulatory conditions is required, differs from the game).

The literary artist acts both as a creator and as a deconstructor of their own creation, and the meaning of the act of destruction of a certain author's construction is no less than in the act of creation, and a creative effect in this case is sometimes even greater (Fig. 2). For example, numerous virtuoso demonstrations of a well-known literary device, followed by its 'exposure', when it turns out that the author only 'tried it on taste', but did not expose this device as a universal instrument to discover reality. One of the typical postmodern techniques of Fowles's writing is an outperformance on the fashion circuit of mass literature.

With the example of the novel The French Lieutenant's Woman (2004), we see the masterful parodic stylization in the spirit of Charles Dickens and William Thackeray, which repeatedly renders the reader into confusion concerning the period of the book. Victorian-themed literary works became fashionable in the 1960s in the UK: sentimental romance and adventure novels about Victorian life began to be published one after another; there were several sensational historical studies (designed for the ordinary reader) in which an attempt was made to destroy the stereotypical representation of the British as slaves of puritanical morality and decency. In an ironic manner, inherent to postmodernism, Fowles takes issue with these popular pseudo-Victorian novels. The writer entices the reader with the Victorian entourage, giving the impression that the book represents the habitual entertaining text, only to deceive the reader's expectations and to offer a new system of values and motivations. All the techniques and means in the eyes of a contemporary artist, who is familiar with the postmodern, are coarse master keys, which actually could not unlock anything. This aspect of the game can be called relativistic.

A language game is close to improvisation as it tries to avoid stagnancy. Thus, it is ideally conceived as a never-ending process: it has a beginning but essentially cannot have any result. Thus, in Fowles's novel The Collector, the consciousness of Caliban is depicted as ordinary so that all stages of detention of the girl Miranda in his house are likened to the stages of a butterfly's life. However, at the same time, he was so refined person that he was deprived of an elementary imagination even at the level of the children's game in the images, which Fowles masterfully brings to the text of the work. "Then we played charades; she acted things, syllables of words, and I had to guess what they were. I wasn't any good at it, either acting or guessing. I remember one word she did was 'butterfly'. She kept on doing it again and again and I couldn't guess" (Fowles, 2004, pp. 21-22).

Thereby, the postmodern element of a game pushes forward an elitist style with a mass phenomenon. Game, as well as paradox, is capable of bringing anything to a light; the game puts everything in its place, shows the improvised roles. Only through the gaming principal is the picture of actual events expressed, but what remains paradoxical is that the picture is shown not in a realistic manner, but presented through the modern perception of reality, or rather, the postmodern.

The technique of creating a border situation is also associated with the element of the game; for example, the role of sin. Sin is subjected to a rethinking in postmodern literature. If to enlist with Miranda's thoughts in relation to the concepts of Caliban, for example, about the area of the sin of adultery, the mere mention of which could plunge Caliban into a shock, then for Miranda this is pure nonsense: "sex is just an activity, like anything else. It's not dirty, it's just two people playing with each other's bodies. Like dancing. Like a game" (Fowles, 2004, p. 43). Thus sin gets a new interpretation - now it is a challenge of life itself - not recklessness, but an act that requires courage and imagination. It turns out that John Fowles helps us to discover new facets of consciousness, while not changing ourselves, not making a revolution inside of 
us. His method is more similar to evolution, because knowledge is already inside of us, it needs only to be discovered. This key is an intimate experience, as a part of the unconscious, by which the door is opened, connecting the unconscious to the conscious. Any previously known result makes the game senseless. The point is not in the end of the plot, but in the development of the plot, in the reflection of the poet's language signs, which are constantly passing through the mass consciousness, a kind of 'laundering' of them from commonplace stereotypes of perception. This is the improvisational aspect of the game.

\section{Results and Discussion}

\section{Semantic Nuances of Postmodern Discourse}

Manipulation of excerpts from the works of other authors is a characteristic moment of postmodernism, confirming the idea that this direction develops mostly on the basis of generalization and refining the creative artistic heritage. As for the phenomenon of intertextuality, we can compare postmodernism with the art of the Dark Ages when the activity of theologians and preachers was actually reduced to the selection of the necessary quotes on a specific theme and interpretation, reflection and reconsideration.

Yu. M. Lotman wrote about the 'dynamic excitation' arising between the encountered texts, especially when they are far apart, such as the texts of European literature of the twentieth century and primitive cultures of the past. According to Lotman, the text could refer to another text as a reality to convention. Playing the opposition of 'real / conditional' is inherent in every situation as 'the text in the text'. The simplest case is the inclusion in the text of an area, encoded by the same way, but by the doubled code as the rest space of the work. This can be a picture in a picture, theater in a theater, film in a film, or novel in a novel. Dual encoding of certain parts of the text, identified with artistic conventions, leads to the fact that the main space of the text is perceived as 'real'. Consciousness also appears in the form of the text that can be read by the relevant rules of grammar (Lotman, 1992), or by using the decryption of signs - symbols and codes.

The decryption process of the model of conditional reality involves verbal, nonverbal, and extra-linguistic signs; disadvantages of reality itself are compensated by its creation in the discursive space. There is a need for special 'postmodern sensitivity' (a term coined by Derrida) to capture semantic nuances introduced by discourse in the linguistic representation of reality. Discourse, as the interpreting instance and the interpreted area, has the unique feature of the simultaneous inclusion of signifier and signified at the same time, depending on the point of view of an author. The process of deciphering the exact language signs of a certain discursive model of reality is possible only through the decryption of the mentally generated sign of a particular entity or phenomenon of the model; deciphering a certain model of reality, according to P. Ricoeur, is the work of thinking, which consists in interpretation of the meaning standing behind the obvious meaning, in revealing the levels of meaning concluded in the literal value (Ricoeur, 1974).

Here it is possible to follow the theory of the sign by Charles Sanders Peirce, which was that the implementation of human thought processes is simply impossible without the help of signs. In tracing the concept of Peirce that 'any thought is a sign' (Hoopes, 1991), the deciphering of certain cognitive acts are not possible without decoding the previous thought processes and actions. Because thinking is an ongoing process, each thought should be interpreted by another thought. Thus, generating a thought is represented only as a fragment in a total chain of decryption, and only there does the thought matter; the essence of a sign is that it is capable of interpreting the thought. Furthermore, according to the works of Pierce, we can reveal that an interpretant (for example, a certain human reaction to the perceived sign; an explanation of the meaning of words by means of other words, etc.) becomes a sign. However, for the cryptanalyst, the meaning origin of the sign matters, not the body of the sign itself. A sign or representamen is the first, standing in a genuine triadic relation to the second, called its object, to be able to determine the kind of the third, called its interpretant (Hoopes, 1991). The analysis of postmodern texts suggests that a thought cannot only be an interpretant, but is a disinterpretant in discourse as well. One of the important questions of semiotic analysis of postmodern discourse involves deciphering the codes existing to interpret all kinds of signs.

Thus, our research addresses the relevant question of the essence of signs (linguistic or non-linguistic) to express the meaning of postmodernism and its 'Proteusism'. The motif of "Proteus" in the postmodern direction is realized at the level of disclosure of a subject of variability and in the comprehension of a logic of antinomies; Proteus presents instant and fantastic reincarnations, highlights the fragility of the boundaries between the real and the imaginary world. In the postmodern novel The Magus (2004) by J. Fowles, Proteus is one of the most important images of illusory reality in the model embodied by the author. Fowles, in his book Wormholes (1988), said that he liked not to know, not to be sure, and just to feel that there is always a space for changes. Literary critic Dianne L. Vipond made a comparison between the image of Proteus and John Fowles: the author eternally destroys finished molded shapes, trying to create or to practice something new (Fowles, 1988). Indeed, the principle of representation is gradually losing its significance 
in postmodernism; there is a theory about the crisis of representation (by Jean Baudrillard), and the blurring of boundaries between reality and text, that focuses attention on the opposition of a sign and the outside world. Thus, postmodernism is a sign construction, a discourse that must be decrypted.

\section{Linguocultural Codes and Discursive Practice}

Postmodernist discourse can be represented as a continuous process of constructing signs, a kind of careful development of the remote sense; postmodernist discourse captures an idea of the instability of life, the lack of integrity and the absence of clear guidelines. To understand the ways of artistic reflection of social transformations in modern society, it is necessary, first of all, to address the concept of metatext. In the first instance, this term can be used for differentiation of a situation in which the text speaks of the world (the reality), from the situation in which the text speaks of the text (metatext situation). 'Metafiction' makes the author and the reader act as heroes of a work of art, bringing them onto the stage in the process of creation or perception of a work of art.

Authors (meta-novelists) do not allow us to remain passive spectators of artistic performances. Mosaic construction of a text of the modern novel resembles a baroque picture of the world, which is characterized by the dissociation of sensibility. The term 'dissociation of sensibility' was coined by T. S. Eliot in his essay, "The Metaphysical Poets" (1921), to define the twentiethcentury violation of the spiritual and the sensual integrity of life, which has had a significant impact on the English poetic tradition. For the postmodern novel, reflecting a Baroque 'dissociation of sensibility', the characteristic features are a fragmentary discourse and a deliberate chaos of composition (Ilyin, 2001).

Other scientists who have studied the organization of textual structures of postmodern works (David Lodge, Douwe W. Fokkema), found ways to create the effect of a deliberate narrative chaos, fragmented discourse of the world as devoid of meaning, law and order. In general, the approach of these researchers describes the ways in which postmodernists show traditional narrative ties in their works and reject the usual principles of narrative organization. According to the critics D. Fokkema and $\mathrm{H}$. Bertens, postmodernists expand the artistic space of the novel by the so-called metatext, which refers to the connotations added by the reader to denotative meaning of the words in the text (Fokkema, Bertens, 1986). These connotations direct the process of understanding by the reader of the text and thus contribute to the emergence of a 'reader's metatext' (Tötösy de Zepetnek, 1998).

Consequently, in postmodern discourse its sign nature gained the particular importance as linguocultural codes, filled with special constituent meaning and requiring special decoding. The peculiarity of postmodern discourse is in many art techniques. Thus, the language identity of the author is shown in a special way of the language of game, the author's improvisation on the famous plots and images of the culture. For example, in Stoppard's play Rosencrantz and Guildenstern Are Dead (1967), we can observe in many respects a similar form of representation of beingness in the American one-act play Forensic \& the Navigators (1996) by Sam Shepard. This play is quite different from the British version of a postmodern play. However, as for hollow characters, fragmentation, illusion and chaos of the recreated space, Shepard's play can serve as a unique example of postmodern aesthetics. The unfolding action, in many respects, is also metaphysical; the action is played out with the main topics of state security, search for terrorists, frustrated expectations, and love.

Though the theme of love does not crown a created intrigue, all we have is a deception of the expectations of the reader/spectator, and the author's game with the absolute concepts of modernAmerican society; confusion and loneliness of the characters, disappointments and loss of the true path. A Statement comes at the end with symbolic smoke on the stage, which envelopes both the stage with the actors and the audience, suggesting the illusory nature of what we spread in society, forgetting the very basis of human morality - love. This final part of the text proclaims the truth, which we sometimes do not see, being distracted by all sorts of noises and "smoke", projected by the social world; we observe the dark side of true life, which is fascinating, which cannot be read by logic. Postmodernism often mixes up concepts, trying to synthetically present a picture of the versatility of life; so it is frequent in postmodern British and American texts (J. DeLillo, J. Fowles, J. Barnes, P. Nichols, et al.), in an attempt to foresee the truth, to represent the Baroque fragmented, unstable, antinomic world (Hakobyan, 2008).

Thus, the action of Sam Shepard's play is declared from the moments of representation of silence and darkness and comes to an end with rhythmic beats and a picture of the stellar sky, indicating the duality of the world around us. A particular interest is that Shepard really antinomicly presents a picture of the universe, which includes the characters of Fonsik and Amity, lost and even confused; characters try reflexively to identify the laws of life, but the fear that implants society has a much greater force, so they cannot win.

\section{Conclusion}

Postmodernist discourse is the synthesis of special language and cultural signs, peculiar codes, realized in the course of cross-cultural and universal communication. The appeal of postmodernism is that in return for a sustainable world modern man is 
offered (but not allotted) such intellectual qualities as independent critical judgment, open-mindedness, tolerance, openness, love for aesthetic diversity, playful looseness, ability for irony and self-irony. The game nature of composite solutions of modern prose creates a labyrinth of signs and motifs associated with the injured consciousness, madness and death, which, incidentally, relates these motifs to the main baroque aesthetic ideas of the unknowable, chaotic life, uncertainties and unconscious ability of a person. The concept of a work of art is already considered as a communicative act, that is, as the process of a complex interaction between the text, the author and the reader. Systematic 'deception' of the reader, encoding whole layers of meaning, deciphering signs and codes are activities guided by the author but producing unknown reactions in the reader and affecting the reader in unknown ways.

The authority of the game was created in many respects by the concepts of linguistic philosophy, where the analysis of language was the analysis of relationship between signs, organized by certain rules of language by game with signs. As a logical culmination there was the theory of 'language games' by Ludwig Wittgenstein, the word autonomy and the postulation of autonomy and self-sufficiency of linguistic resources in the theory of deconstruction coined by Derrida. Lyotard declared 'language games' as any social interaction within the two types of discourse: the scientific and the narrative. He opposed these types of discourse nearly in all aspects except one: they are language (meta) games as they are innovative and agonistic. In the postmodern state, Lyotard sees the crisis of narrative discourse of culture in connection with its groundlessness in the context of practical actualization of human capabilities: nonscientific knowledge is unproductive.

But the crucial statement here is that the narrative form, in contrast to the developed forms of discourse of knowledge, allows a multiplicity of language games within itself (Lyotard, 1984). Thus, art and culture are directly allocated the status of game forms of activity.

Interpretation of postmodern discourse is possible with the help of linguocultural and other codes and subcodes, deciphering cultural signs, symbols, concepts that are involved in the process of cross-cultural and universal communication. The system of codes, which are the main keys to the interpretation of postmodern discourse, includes: linguistic, cultural, semiological, interactive, hermeneutical, meta-textual codes and existential sub-code.

Postmodern discourse intersects discourses of the author, the reader and the characters, leading to a purging of syntax and punctuation borders between them and fixes the lack of clarity, consistency and hierarchy of narration. In the course of analysis of postmodern discourse of English-speaking writers, the frequent use of new techniques, typical for these type of texts, was revealed: reducing of statements; spelling and punctuation anomalies and so forth, indicating the fragmentation of discourse. Language code in its conjunction with other codes is the basis of postmodern discourse. So, for example, the cultural code represents the cultural space as a major factor in the development of the postmodern discourse and takes into account the system of concepts encoded in verbal and nonverbal signs of language consciousness of postmodernism. Language consciousness in postmodern discourse reflects cross-cultural universal codes (discourseuniverse), contributing to the deciphering of cultural realities and to overcoming of cultural distance between the author and the reader.

Communication between the segments/codes of a different order is organized on the principle of juxtaposition and the chaotic flow of consciousness. Thus, in postmodern discourse, the principle of interaction of space and time is violated; it begins to be an infinite semiosis, that is, the interpretation of signals (signs), perceived by the reader. The symbolic reading of the work suggests a multiplicity of interpretations as definitive of postmodern discourse. The symbols in postmodern literary texts are an important sign of postmodern discourse, as they are indicated by the words-in-text, keywords, forming the concepts of the discourse-universe or of the language picture of the world.

\section{References}

Bakhtin, M. M. (1979). Jestetika slovesnogo tvorchestva [Aesthetics of verbal creativity]. Moscow, USSR: Iskusstvo.

Bakhtin, M. M. (2000). Frejdizm. Formal'nyj metod $v$ literaturovedenii. Marksizm i filosofija jazyka [Freudianism. A formal method in literary criticism. Marxism and the philosophy of language]. Moscow, Russia: Labyrinth.

de Saussure, F. (1998). Course in general linguistics. Chicago, IL: Open Court Publishing Company.

Fowles, J. (1988). Wormholes: Essays and occasional writings. New York, NY: Owl Books, Henry Holt.

Fowles, J. (2004). The collector. New York, NY: Random House, Inc.

Greimas, A.-J., \& Coutes, J. (1993). Semiotique. Dictionnaire raisonne de la theorie du language [Semiotics. Dictionary of language theory]. Paris, France: Hachette Superieur.

Hakobyan, K. (2008). Postmodernistskoe videnie mira v britanskoj i amerikanskoj p'ese (na materiale p'es T. Stopparda i S. Sheparda) [The postmodern vision of the world in British and American play (based on the plays by T. Stoppard and S. Shepard)]. In A. 
P. Timonina (Ed.), Jazykovye i kul'turnye kontakty razlichnyh narodov (pp. 133-135). Moscow, Russia: Penzenskij gos. ped. un-t im. V. G. Belinskogo.

Hoopes, J. (1991). Peirce on signs: Writings on semiotic by Charles Sanders Peirce. Chapel Hill, NC: University of North Carolina Press.

Ilyin, I. P. (2001). Postmodernizm [Postmodernism]. Moscow, Russia: Intrada.

Isaev, S. (1992). Kak vsegda ob avangarde: Antologija francuzskogo teatra avangarda [As always the avantgarde: An anthology of French avant-garde theater]. Moscow, Russia: GITIS.

Kashkin, V. B. (2007). Sopostavitel'naja lingvistika [Comparative linguistics]. Voronezh, Russia: Voronezh State University Press.

Lacan, J. (1977). Écrits: A selection [Writings: A selection]. New York, NY: W. W. Norton \& Co.

Lotman, Yu. M. (1970). Struktura hudozhestvennogo teksta [The structure of the literary text]. Moscow, USSR: Iskusstvo.

Lotman, Yu. M. (1992). Stat'i po semiotike i topologii kul'tury [Articles on semiotics and cultural topology]. Tallinn, Estonia: Aleksandra.

Lyotard, J.-F. (1984). The postmodern condition. Manchester, UK: Manchester University Press.

Dranov, A., Ilyin, I., \& Kozlov, A. (1996). Sovremennoe zarubezhnoe literaturovedenie: Strany Zapadnoj Evropy i SShA: Koncepcii, shkoly, terminy [Modern foreign literature: Western Europe and the United States: Concepts, schools, terms]. Moscow, Russia: Intrada.

Uhvanova-Shmygova, I. F. (2009). Metodologija issledovanij politicheskogo diskursa: Aktual'nye problemy soderzhatel'nogo analiza obshhestvennopoliticheskih tekstov. Politicheskoe pole Belarusi glazami diskurs-analitika [Research on methodology of political discourse: Actual problems of meaningful analysis of the socio-political texts. The political field of Belarus through the eyes of discourse analyst]. Minsk, Belarus: BSU Publishing House.

Ricoeur, P. (1974). The conflict of interpretations: Essays in hermeneutics. Evanston, IL: Northwestern University Press.

Stepanov, Yu. S. (1996). Al'ternativnyj mir, diskurs, fakt i princip prichinnosti [Alternative world, discourse, fact and the principle of causality]. In Yu. S. Stepanov (Ed.), Jazyk i nauka konca XX veka (pp. 35-73). Moscow, Russia: RGGU.

Szczerba, L. V. (2004). Jazykovaja sistema i rechevaja dejatel'nost' [Language system and speech activity]. Moscow, Russia: URSS.

Tötösy de Zepetnek, S. (1998). Comparative literature. Theory, method, application. Amsterdam, Netherlands: Editions Rodopi. de Courtenay, B. (1963). Izbrannye trudy po obshhemu jazykoznaniju [Selected works on general linguistics]. Moscow, USSR: Izdatelstvo Academii Nauk.

Derrida, J. (1973). "Speech and phenomena" and other essays on Husserl's theory of signs. Evanston, IL: Northwestern University Press.

Kristeva, J. (2000). Crisis of the European subject. New York, NY: Other Press.

Allen, W. (1964). Tradition and dream: The English and American novel from the twenties to our time. London, UK: Phoenix House.

Kubryakova, E. S. (2004). Jazyk i znanie: Na puti poluchenija znanij o jazyke: Chasti rechi s kognitivnoj tochki zrenija. Rol' jazyka v poznanii mira [Language and knowledge: Towards learning about language: Parts of speech with a cognitive point of view. The role of language in the knowledge of the world]. Moscow, Russia: Yazyki slavyanskoy kultury.

Alexandrova, O. V., Kubryakova, E. S. (1997). Vidy prostranstv teksta i diskursa [Types of text and discourse spaces]. In E. S. Kubryakova, O. V. Alexandrova (Eds.), Kategorizacija mira: Prostranstvo i vremja (pp. 15-25). Moscow, Russia: Dialog-MSU.

Kostomarov, V.G.(1999). Jazykovoj vkus jepohi [Language taste of the era]. St. Petersburg, Russia: Zlatoust.

Zarubina, N. D. (1981). Tekst: Lingvisticheskij $i$ metodicheskij aspekty [Text: Linguistic and methodical aspects]. Moscow, USSR: Russkij jazyk.

Arutyunova, N.D. (1990). Jazyk i mir cheloveka [Language and world of a human]. Moscow, USSR: Progress.

Karaulov, Yu. N. (2010). Russkij jazyk i jazykovaja lichnost' [The Russian language and language person]. Moscow, Russia: LKI.

Mironova, N. N. (1998). Diskurs-analiz ocenochnoj semantiki [Discourse analysis of evaluative semantics]. Moscow, Russia: Thesaurus.

Foucault, M. (2005). Gesammelte schriften [Collected writings]. Frankfurt am Main, Germany: Suhrkamp.

Kristeva, J. (1993). Bahtin, slovo, dialog i roman [Bakhtin, the word, the dialogue, and the novel]. Dialog. Karnaval. Hronotop, 4, 5-24.

Fowles, J. (2004). The French lieutenant's woman. London, UK: Vintage.

Fowles, J. (2004). The magus. London, UK: Vintage.

Fokkema, D., Bertens, H. (1986). Approaching postmodernism. Amsterdam, Netherlands: John Benjamins Publishing Company.

Stoppard, T. (1967). Rosencrantz and Guildenstern are dead. London, UK: Faber and Faber.

Shepard, S. (1996). The unseen hand: And other plays. London, UK: Vintage. 